Supplement of Biogeosciences, 13, 3397-3426, 2016

http://www.biogeosciences.net/13/3397/2016/

doi:10.5194/bg-13-3397-2016-supplement

(C) Author(s) 2016. CC Attribution 3.0 License.

(c) (i)

Supplement of

\title{
Estimate of changes in agricultural terrestrial nitrogen pathways and ammonia emissions from 1850 to present in the Community Earth System Model
}

Stuart Riddick et al.

Correspondence to: Peter Hess (pgh25@cornell.edu)

The copyright of individual parts of the supplement might differ from the CC-BY 3.0 licence. 
Table S1 Site description and measurement method used to compare with model prediction from manure

\begin{tabular}{|c|c|c|c|c|c|}
\hline $\begin{array}{l}\text { Site } \\
\text { Location }\end{array}$ & Source & $\begin{array}{l}\text { Site } \\
\text { Description }\end{array}$ & $\#$ & $\begin{array}{l}\text { Date of } \\
\text { measurement }\end{array}$ & $\begin{array}{l}\text { Average } \\
\text { Temperature } \\
\left({ }^{\circ} \mathrm{C}\right)\end{array}$ \\
\hline Texas, USA & $\begin{array}{l}\text { Todd et al., } \\
2007\end{array}$ & $\begin{array}{l}\text { Commercial } \\
\text { beef cattle } \\
\text { feedyard. }\end{array}$ & $\begin{array}{l}1 \\
2 \\
3 \\
4 \\
5\end{array}$ & $\begin{array}{r}\text { August } 2002 \\
\text { July } 2003 \\
\text { June } 2004 \\
\text { January } 2003 \\
\text { February } 2004\end{array}$ & $\begin{array}{r}25 \\
28 \\
23 \\
1 \\
2\end{array}$ \\
\hline $\begin{array}{l}\text { The } \\
\text { Netherlands }\end{array}$ & Bussink, 1992 & $\begin{array}{l}\text { Dairy cow } \\
\text { grazing. } \\
\text { Ryegrass. }\end{array}$ & $\begin{array}{l}6 \\
7 \\
8 \\
9 \\
10 \\
11 \\
12 \\
13 \\
14 \\
15 \\
16 \\
17 \\
18\end{array}$ & $\begin{array}{r}\text { May } 1987 \\
\text { June } 1987 \\
\text { July } 1987 \\
\text { August } 1987 \\
\text { September } 1987 \\
\text { October } 1987 \\
\text { May } 1988 \\
\text { June } 1988 \\
\text { July } 1988 \\
\text { August } 1988 \\
\text { September } 1988 \\
\text { October } 1988 \\
\text { September } 1989\end{array}$ & $\begin{array}{l}13 \\
15 \\
17 \\
18 \\
14 \\
11 \\
12 \\
14 \\
16 \\
17 \\
14 \\
11 \\
12\end{array}$ \\
\hline $\begin{array}{l}\text { The } \\
\text { Netherlands }\end{array}$ & Bussink, 1994 & $\begin{array}{l}\text { Dairy cow } \\
\text { grazing. } \\
\text { Ryegrass. }\end{array}$ & $\begin{array}{l}19 \\
20 \\
21 \\
22\end{array}$ & $\begin{array}{r}\text { May } 1989 \\
\text { June } 1989 \\
\text { July } 1989 \\
\text { August } 1989\end{array}$ & $\begin{array}{l}10 \\
11 \\
13 \\
15\end{array}$ \\
\hline UK & $\begin{array}{l}\text { Jarvis et al., } \\
1989\end{array}$ & $\begin{array}{l}\text { Beef cattle } \\
\text { grazing } \\
\text { land. } \\
\text { Ryegrass }\end{array}$ & $\begin{array}{l}23 \\
24 \\
25 \\
26 \\
27 \\
28 \\
29\end{array}$ & $\begin{array}{r}\text { May } 1987 \\
\text { June } 1987 \\
\text { July } 1987 \\
\text { August } 1987 \\
\text { September } 1987 \\
\text { October } 1987 \\
\text { November } 1987\end{array}$ & $\begin{array}{l}13 \\
16 \\
22 \\
21 \\
19 \\
15 \\
13\end{array}$ \\
\hline Texas, USA & $\begin{array}{l}\text { Flesch et al., } \\
2007\end{array}$ & $\begin{array}{l}\text { Commercial } \\
\text { beef cattle } \\
\text { feedyard. }\end{array}$ & $\begin{array}{l}30 \\
31\end{array}$ & $\begin{array}{r}\text { June } 2004 \\
\text { April } 2005\end{array}$ & $\begin{array}{l}23 \\
20\end{array}$ \\
\hline $\begin{array}{l}\text { Alabama, } \\
\text { USA }\end{array}$ & $\begin{array}{l}\text { Mulvaney et } \\
\text { al., } 2008\end{array}$ & $\begin{array}{l}\text { Dairy cattle } \\
\text { pasture } \\
\text { land. }\end{array}$ & $\begin{array}{l}32 \\
33 \\
34 \\
35 \\
\end{array}$ & $\begin{array}{r}\text { June } 2003 \\
\text { September } 2003 \\
\text { January } 2004 \\
\text { April } 2004 \\
\end{array}$ & $\begin{array}{l}25 \\
22 \\
10 \\
20 \\
\end{array}$ \\
\hline Switzerland & $\begin{array}{l}\text { Spirig et al., } \\
2010\end{array}$ & $\begin{array}{l}\text { Cattle } \\
\text { slurry, } \\
\text { managed } \\
\text { grassland }\end{array}$ & $\begin{array}{l}36 \\
37 \\
38 \\
39 \\
40 \\
41\end{array}$ & $\begin{array}{r}\text { July } 2006 \\
\text { September } 2006 \\
\text { October } 2006 \\
\text { April } 2007 \\
\text { July } 2007 \\
\text { October } 2007\end{array}$ & $\begin{array}{r}19 \\
15 \\
9 \\
9 \\
19 \\
9\end{array}$ \\
\hline
\end{tabular}




\begin{tabular}{|c|c|c|c|c|c|}
\hline Spain & $\begin{array}{l}\text { Sanz et al., } \\
2010\end{array}$ & $\begin{array}{l}\text { Pig slurry, } \\
\text { arable land }\end{array}$ & 42 & September 2006 & 20 \\
\hline Switzerland & $\begin{array}{l}\text { Sintermann et } \\
\text { al., } 2011\end{array}$ & $\begin{array}{l}\text { Cattle } \\
\text { slurry, } \\
\text { arable/grass }\end{array}$ & $\begin{array}{l}43 \\
44\end{array}$ & $\begin{array}{l}\text { August } 2009 \\
\text { August } 2009\end{array}$ & $\begin{array}{l}18 \\
18\end{array}$ \\
\hline
\end{tabular}

Table S2 Site description and measurement method used to compare with model prediction from fertilizer

\begin{tabular}{llllll}
\hline Site Location & Source & $\begin{array}{l}\text { Site } \\
\text { Description }\end{array}$ & $\#$ & Year & Lat. \\
\hline Canterbury, NZ & Black et al., 1985 & Pasture & 1 & 1983 & -43 \\
Canterbury, NZ & Black et al., 1985 & Pasture & 2 & 1984 & -43 \\
Canterbury, NZ & Black et al., 1989 & Sown wheat & 3 & 1985 & -43 \\
Queensland, Australia & Catchpoole et al., 1983 & Pasture & 4 & 1982 & -28 \\
Texas, USA & Hargrove \& Kissel, 1979 & Turf & 5 & 1976 & 33 \\
Illinois, USA & Goebes et al., 2003 & Cropland & 6 & 2000 & 38 \\
Georgia, USA & Vaio et al., 2008 & Pasture & 7 & 2004 & 31 \\
Kentucky, USA & Bowman et al., 1987 & Turf & 8 & 1985 & 37 \\
Ontario, Canada & Sheard \& Beauchamp, 1985 & Turf & 9 & 1985 & 43 \\
Vancouver, Canada & Nason et al., 1998 & Forest & 10 & 1986 & 50 \\
\hline
\end{tabular}

\section{Bounds for the sensitivity experiments:}

Here we discuss the bounds chosen for the various sensitivity experiments (Table 1 and Table 2). In the first set of experiments on the manure (EX1m, EX2m) we control for the mechanical mixing of manure into the soil. Estimates for the diffusivity of bioturbation alone vary by an order of magnitude (Koven et al., 2013) depending on location. Tillage, grazing animals and other agriculture practices would also be expected to impact this mixing rate. Therefore we set large bounds on the timescale for this coefficient coefficient at 100 and 750 days, with the default value set at 365 days in the control experiment. Experiments EX3 and EX4 modified the adjustment time of the water within the TAN pool to the soil water for both the fertilizer and manure pools. Very little available guidance is available for choosing this parameter and therefore we varied it from diurnal (1 day) to synoptic timescales (10 days). Reasonable bounds for variations in $\mathrm{pH}$ are approximately between 6 and 8 (EX5, EX6, 
EX7). In Eghball et al. (2000) the majority of the reported measurements of $\mathrm{pH}$ for beef cattle feedlot manure are between 7 and 8 , although in one case a $\mathrm{pH}$ of 8.8 was measured. The recommended $\mathrm{pH}$ for various crops ranges from approximately 5.8 to 7.0 depending on the crop (e.g., http://onondaga.cce.cornell.edu/resources/soil-ph-for-field-crops). In EX7 we use the ISRIC-WISE dataset (Batjes, 2005) imported dataset for soil $\mathrm{pH}$, but this dataset does not account for $\mathrm{pH}$ changes in agriculturally amended soils. The canopy capture fraction (EX8, EX9) can vary considerably depending on vegetation type and season. Here we bounded the sensitivity calculations at canopy capture fractions of 0.4 and 0.8 . Note, however, ammonia emissions are linearly dependent on this parameter (equation 8) so additional sensitivity tests are not warranted. The background $\mathrm{NH}_{3}$ concentration has considerable spatial and temporal heterogeneity (EX10, EX11). To investigate the effects of this, uncertainty bounds were set for background ammonia concentrations at 0.1 and $1 \mu \mathrm{g} \mathrm{m} \mathrm{m}^{-3}$ for the lower and upper bound as representative of clean and moderately polluted sites (Warner et al., 2016). The sensitivity to the $\mathrm{H} 2 \mathrm{O}$ depth is tested in simulations EX12 and EX13. The $\mathrm{H} 2 \mathrm{O}$ depth is essentially taken as the mixing depth of the manure or fertilizer, the depth to which the nitrogen equilibrates with the soil water. The bounds are picked as correspond to shallow mixing $(2 \mathrm{~cm})$ and deeper mixing $(10 \mathrm{~cm})$. The diffusion timescale for the mixing of ammonia into the soils $\left(K_{D}\right)$ is varied in simulations EX14 and EX15. This timescale depends on the water content, the base diffusion rate, the soil porosity, and a length scale of which the diffusion operates over (Table S1, supplement). While the water content is determined internally within the CLM all the other factors are set globally. We take $\pm 50 \%$ as a reasonable bound on $K_{D}$. The maximum rate of nitrification $\left(r_{\max }\right)$ is taken from Parton et al, 2001. In sensitivity experiments EX16 and EX17 we take $\pm 50 \%$ as reasonable bounds on this parameter. Sensitivities for experiments EX18m, EX18f, EX19f and EX20f varying the characteristics of manure or fertilizer input are given in the text. 